\title{
Hyperinsulinism-hyperammonemia syndrome
}

INSERM

\section{Source}

INSERM. (1999). Orphanet: an online rare disease and orphan drug data base. Hyperinsulinism-hyperammonemia syndrome. ORPHA:35878

Hyperinsulinism-hyperammonemia syndrome (HIHA) is a frequent form of diazoxidesensitive diffuse hyperinsulinism (see this term), characterized by an excessive/ uncontrolled insulin secretion (inappropriate for the level of glycemia), asymptomatic hyperammonemia and recurrent episodes of profound hypoglycemia induced by fasting and protein rich meals, requiring rapid and intensive treatment to prevent neurological sequelae. Epilepsy and cog nitive deficit that are unrelated to hypoglycemia may also occur. 